\title{
Effect of solar radiation and flaxseed supplementation on milk production and fatty acid profile of lactating ewes under high ambient temperature
}

\author{
M. Caroprese, ${ }^{* 1}$ M. Albenzio, ${ }^{*}$ A. Bruno, $\dagger$ V. Fedele, $\dagger$ A. Santillo, ${ }^{*}$ and A. Sevi ${ }^{*}$ \\ *Department of Production and Innovation in Mediterranean Agriculture and Food Systems (PriMe), Università di Foggia, Via Napoli 25, \\ 71100 Foggia, Italy \\ †CRA-Istituto Sperimentale per la Zootecnia, Segezia, 71020 Foggia, Italy
}

\begin{abstract}
The objectives of this study were to evaluate the effects of protection from solar radiation and whole flaxseed supplementation on milk yield and milk fatty acid profile in lactating ewes exposed to high ambient temperature. The experiment was conducted during summer and involved 40 ewes divided into 4 groups. The ewes were either exposed (not offered shade) or protected from solar radiation (offered shade). For each solar radiation treatment, ewes were supplemented with whole flaxseed or not. Milk samples from each ewe were collected at the morning and afternoon milking every week, and analyzed for $\mathrm{pH}$, total protein, casein, fat, and lactose content, somatic cell count, and renneting parameters (clotting time, rate of clot formation, and clot firmness after $30 \mathrm{~min}$ ). At the beginning of the experiment, and then at d 23 and 44, milk samples were analyzed for milk fatty acids using gas chromatography. Flaxseed supplementation significantly increased milk yield, fat, protein, and casein yields, and somatic cell count, and increased fat and lactose contents of milk. A decrease of saturated fatty acids from C6:0 to C16:0 and an increase of C18:1 trans-11 and C18:2 cis-9,trans-11 was observed in milk from flaxseed-supplemented ewes. Flaxseed supplementation decreased saturated fatty acids content and increased total monounsaturated fatty acids content, the total content of isomers of conjugated linoleic acid, and polyunsaturated fatty acids content in milk. Flaxseed also increased the $\alpha$-linolenic acid content of milk. As a result, milk from supplemented groups showed an increase in n-3 fatty acid content. Flaxseed supplementation decreased short-chain and medium-chain fatty acids, and increased long-chain fatty acid content of milk. On average, flaxseed supplementation increased the $\mathrm{C} 18: 2$ cis-9,trans-11/C18:1 trans- $11 \Delta^{9}$-desaturase index starting from d 23 of the experiment, in correspondence with the highest C18:2 cis-9,trans-11 content
\end{abstract}

Received December 6, 2010.

Accepted April 7, 2011.

${ }^{1}$ Corresponding author: m.caroprese@unifg.it of milk from flaxseed-supplemented ewes. Flaxseed decreased atherogenic and thrombogenic indices of milk. Protection from solar radiation during summer did not improve yield and composition of ewe milk. Nevertheless, milk from ewes exposed to solar radiation showed decreased long-chain fatty acid and polyunsaturated fatty acids contents, and in particular, decreased vaccenic acid, rumenic acid, and total conjugated linoleic acid contents.

Key words: polyunsaturated fatty acid, sheep milk, high ambient temperature, flaxseed

\section{INTRODUCTION}

Sheep milk is entirely destined for dairy products, in particular cheese. Consequently, it is desirable for sheep milk to contain high contents of fat and protein to produce high-quality cheese. During summer in the Mediterranean basin, lactating ewes exposed to temperature-humidity index (THI) >80 exhibit a 20\% reduction in milk yield (Sevi et al., 2001). The increase in ambient temperatures and the advancement of lactation contribute to a reduction in mobilization of body reserve for milk synthesis, thus inducing a decrease of milk yield and of fat and casein yields. It has been observed that exposure to direct solar radiation adversely influences the fat composition of sheep milk, with a decrease in unsaturated fatty acids and an increase in saturated fatty acids (Sevi et al., 2002).

Milk is an important source of vaccenic acid (C18:1 trans-11, VA), which is an intermediate of rumen biohydrogenation of linoleic and linolenic acids, and which is converted to rumenic acid (C18:2 cis-9,trans-11, RA) by $\Delta^{9}$-desaturase in the mammary gland. Rumenic acid is the major isomer of total conjugated linoleic acid (CLA) of milk fat, and both VA and RA are considered health-promoting fatty acids (McGuire and McGuire, 2000). In ewe milk, Nudda et al. (2005) observed a reduction of VA and RA with the advancement of lactation, with the lowest values being recorded during summer.

Under high ambient temperatures, the provision of shaded areas, although contributing to the maintenance 
of ewe thermal balance, did not result in increased ewe production performance (Sevi et al., 2001). However, shaded ewes showed an increase in mammary defense ability and an improvement of milk hygienic quality.

Fat supplementation has been suggested as a strategy to increase the ration energy of the diet and reduce the adverse effects of heat stress on dairy cows; however, fat supplementation can adversely affect both milk yield and fat content (Liu et al., 2008) or only fat content of milk (Drackley et al., 2003). In addition to the improvement of physiological responses and production in heat-stressed animals, the supplementation of fat to the ruminant diet has been used to improve the fatty acid profile of milk. In sheep, several studies have found that the administration of fat supplement can change the fatty acid profile of milk to meet human dietary recommendations by a decrease of saturated and an increase of unsaturated fatty acids (Rotunno et al., 1998; Zhang et al., 2006a,b). However, lactating ewes receiving dietary fat supplementation display decreased milk yield and protein content, with adverse effects on cheese yield and quality (Rotunno et al., 1998; Toral et al., 2010a,b). To the best of our knowledge, no studies have tested the effect of fat supplementation on lactating ewes subjected to heat stress. The administration of whole flaxseed as fat supplement to cows raised under high ambient temperature sustains cow immune functions and improves the yield, composition, and nutritional properties of milk by enhancing the VA, RA, and polyunsaturated fatty acids (PUFA) contents of milk (Caroprese et al., 2009, 2010).

We hypothesized that the provision of shaded areas and administration of flaxseed rich in lipid content to the diet of lactating ewes subjected to a hot environment could sustain milk yield and improve the fatty acid profile of milk. Therefore, this work was conducted to evaluate the effects of protection from solar radiation and whole flaxseed supplementation on the production performance of lactating ewes and on milk fatty acid profile under high ambient temperatures.

\section{MATERIALS AND METHODS}

\section{Animals and Experimental Design}

The experiment lasted $44 \mathrm{~d}$ and was conducted during the summer (July and August 2007) at the Segezia research station of the Council for Research and Experimentation in Agriculture (CRA-ZOE). Forty latelactation Sarda ewes (d 202.1 \pm 5.3 of lactation, mean $\pm \mathrm{SD}$ ) were divided into 4 groups of 10 each, balanced for parity $(2.6 \pm 0.7)$, milk yield $(740.5 \pm 9.43 \mathrm{~g} / \mathrm{d})$, BW $(39.11 \pm 0.26 \mathrm{~kg})$, and BCS $(1.61 \pm 0.06)$. During the study, animals were either exposed to (EXP; not offered shade) or protected from solar radiation (PRO; offered shade). Groups were separately reared in external pens of $5 \times 12 \mathrm{~m}$ bounded with mesh fence. Shade was provided by $3-\times 8-\mathrm{m}$ and 3.5-m-high brickwork rooms adjacent to the open pens; the trough and the crib were located in the external areas. Both exposed and protected animals were fed twice daily with vetch and oat hay and pelleted concentrate (Pecorlat 19, Raggio di sole mangimi SpA, Potenza, Italy; EXP-C and PRO-C groups); EXP-F and PRO-F ewes were supplemented with $21 \%$ whole flaxseed (Lin Tech, Tecnozoo srl, Torreselle di Piombino Dese, Italy). Ingredients of the diets are reported in Table 1. Dry matter intake was determined for each experimental group by weighing the refusals at $0800,1200,1600$, and 2000 h. Averages of daily DMI were 2.12, 2.09, 2.13, and $2.10 \mathrm{~kg} /$ ewe in EXP-C, EXP-F, PRO-C, and PRO-F groups, respectively. Water was available ad libitum for all groups from automatic drinking troughs at any time of day.

During the trial, ambient temperature and relative humidity in protected and exposed area were monitored with thermo-hygrographs (LSI, I-20090 Settala Premenugo-Milano, Italy) placed $1.5 \mathrm{~m}$ from the floor. Average of THI was calculated using the Kelly and Bond (1971) formula.

\section{Chemical Composition of Diets}

The chemical composition of vetch and oat hay, pelleted concentrate and whole flaxseed was carried out by standard procedures (AOAC, 1990): CP, fat (by ether extract), NDF, ADF, and acid detergent lignin were analyzed. Net energy for lactation was calculated using NRC (2001). The chemical composition of the diets is reported in Table 1.

Table 1. Ingredients and chemical composition of the diets (DM basis)

\begin{tabular}{lcc}
\hline Item & $\begin{array}{c}\text { Control } \\
\text { diet }\end{array}$ & $\begin{array}{c}\text { Flaxseed- } \\
\text { supplemented } \\
\text { diet }\end{array}$ \\
\hline $\begin{array}{l}\text { Ingredients, \% of DM } \\
\text { Vetch and oat hay }\end{array}$ & 60.77 & 60.37 \\
Concentrate $^{1}$ & 39.23 & 31.18 \\
$\quad$ Whole flaxseed & & 8.45 \\
Chemical composition & 0 & \\
DM, \% & & 90.79 \\
Ether extract, \% of DM & 90.56 & 4.75 \\
CP, \% of DM & 2.71 & 13.03 \\
ADF, \% of DM & 12.89 & 26.06 \\
NDF, \% of DM & 25.51 & 49.21 \\
ADL, \% of DM & 50.14 & 3.01 \\
NE, Mcal/kg & 2.99 & 1.36 \\
\hline
\end{tabular}

${ }^{1}$ Percolat 19 (Raggio di sole mangimi SpA, San Nicola di Melfi, Italy). ${ }^{2}$ Lin Tech (Tecnozoo srl, Torrreselle di Piombino Dese, Italy). 
Lipid extraction for fatty acid analysis of the diet ingredients was carried out according to a modified Folch method (Ardvisson et al., 2009). Separation and quantification of the methyl esters were carried out using a gas chromatograph (Agilent 6890N) equipped with a flame-ionization detector, autosampler, split injection port, and a fused silica capillary column $(100 \mathrm{~m}$, internal diameter $0.25 \mathrm{~mm}$, film thickness $0.25 \mu \mathrm{m}$; HP-88 capillary column, Agilent Technologies SpA, Cernusco sul Naviglio, Milan, Italy). Helium was used as the gas carrier $(0.42 \mathrm{~mL} / \mathrm{min})$. Injector temperature was maintained at $220^{\circ} \mathrm{C}$ whereas the detector temperature was of $250^{\circ} \mathrm{C}$. Fatty acid profile was determined using the following temperature gradient program: initial temperature of $150^{\circ} \mathrm{C}$ that was increased to $220^{\circ} \mathrm{C}$ at $1^{\circ} \mathrm{C} / \mathrm{min}$. Each peak was identified and quantified using pure methyl ester standards: 37-component FAME mixture and methyl trans vaccenate C18:1 trans-11 octadecenoate (Matreya Inc., Pleasant Gap, PA); CLA isomers were identified by comparison of retention times with CLA methyl ester standards: C18:2 cis-9,trans-11 octadecadienoate and methyl C18:2 trans-10, cis-12 octadecadienoate (Matreya Inc.). Results were expressed as grams per 100 grams of total fatty acids analyzed (Table 2).

\section{Sampling and Chemical Analyses of Milk}

Ewes were milked twice daily (0700 and $1400 \mathrm{~h}$ ) in a parlor using a pipeline milking machine (Alfa Laval Agri, Tumba, Sweden). Milk samples from each ewe were collected at the morning and afternoon milkings once a week on the same day throughout the experiment. One aliquot was stored at $-20^{\circ} \mathrm{C}$ for fatty acid analysis. Fresh samples were used for the following chemical analysis: pH (GLP 21 Crison, Barcelona, Spain), total protein, casein, fat, and lactose contents using an infrared spectrophotometer (MilkoScan FT120, Foss Electric, Hillerød, Denmark) according to the International Dairy Federation standard (IDF, 1990), and SCC using a Fossomatic Minor (Foss Electric; IDF, 1995). Evaluation of the renneting parameters (clotting time, rate of clot formation, and clot firmness after 30 min) was measured by a Foss Electric formagraph. The milk coagulating index $(\mathbf{C o I})$ was calculated as the clot firmness to clotting time + rate of clot formation ratio.

\section{Milk Fatty Acid Analysis}

At the beginning of the experiment and then at $\mathrm{d} 23$ and 44, each milk sample was analyzed for milk fatty acids. Milk fat was extracted according to the procedure of Luna et al. (2005) and transesterification of fatty acids according to ISO-IDF (2002) procedures, as reported in Caroprese et al. (2010). Briefly, fatty acid methyl esters were separated and measured using a gas chromatograph (Agilent 6890N) equipped with CP-Sil 88 fused-silica capillary column $(100 \mathrm{~m} \times 0.25 \mathrm{~mm}$ i.d. with $0.25-\mu \mathrm{m}$ film thickness). Operating conditions were a helium flow rate of $1 \mathrm{~mL} / \mathrm{min}$, a flame-ionization detector at $260^{\circ} \mathrm{C}$, a split-splitless injector at $260^{\circ} \mathrm{C}$, and an injection volume of $1 \mu \mathrm{L}$ with a split ratio 1:50. The temperature program of the column was set at $100^{\circ} \mathrm{C}$ with a subsequent increase to $240^{\circ} \mathrm{C}$ at $3.5^{\circ} \mathrm{C} /$ min and held for 15 min. Fatty acid were reported as grams per 100 grams of FA. The content of short-chain fatty acids (C4:0 to C12:1, SCFA), medium-chain fatty acids (C14:0 to C16:1, MCFA) and long-chain fatty acids (>C18:0, LCFA) were calculated. Saturated fatty acids (SFA), monounsaturated fatty acids (MUFA), and PUFA were calculated. The desaturase indexes were calculated as described by Kelsey et al. (2003). Atherogenic (AI) and thrombogenic (TI) indices were calculated according to Ulbricht and Southgate (1991) formula:

$$
\begin{gathered}
\mathrm{AI}=(\mathrm{C} 12: 0+4 \times \mathrm{C} 14: 0+\mathrm{C} 16: 0) /[\Sigma \text { MUFA } \\
+\Sigma \mathrm{PUFA}(\mathrm{n}-6) \text { and }(\mathrm{n}-3)] \\
\mathrm{TI}=(\mathrm{C} 14: 0+\mathrm{C} 16: 0+\mathrm{C} 18: 0) /[0.5 \times \Sigma \mathrm{MUFA} \\
+0.5 \times \Sigma \operatorname{PUFA}(\mathrm{n}-6)+3 \times \Sigma \operatorname{PUFA}(\mathrm{n}-3) \\
+(\mathrm{n}-3) /(\mathrm{n}-6)] .
\end{gathered}
$$

Table 2. Fatty acid composition (g/100 g of total fatty acids) of feed ingredients

\begin{tabular}{lcrr}
\hline Fatty acid & $\begin{array}{c}\text { Vetch and } \\
\text { oat hay }\end{array}$ & Concentrate $^{1}$ & $\begin{array}{c}\text { Whole } \\
\text { flaxseed }^{2}\end{array}$ \\
\hline C16:0 & 20.21 & 16.09 & 5.62 \\
C18:0 & 2.66 & 2.64 & 3.67 \\
C18:1 cis-9 & 14.15 & 19.05 & 19.50 \\
C18:2n-6 cis-9, cis-12 & 20.48 & 53.73 & 16.15 \\
C18:3n-3 & 24.17 & 6.87 & 54.03 \\
Other fatty acids & 18.35 & 1.77 & 1.18 \\
\hline
\end{tabular}

${ }^{1}$ Percolat 19 (Raggio di sole mangimi SpA, San Nicola di Melfi, Italy).

${ }^{2}$ Lin Tech (Tecnozoo srl, Torrreselle di Piombino Dese, Italy). 


\section{Statistical Analysis}

All variables were tested for normality using the Shapiro-Wilk test (Shapiro and Wilk, 1965). Data were processed using ANOVA for repeated measures (SAS Institute, 1999), with exposure to solar radiation (nonrepeated factor), diet (nonrepeated factor), the time of sampling, and their interactions as repeated factors. Individual animals were nested within treatments. Where significant effects were found $(P<0.05)$, Student's $t$ test was used to locate significant differences between means.

\section{RESULTS}

\section{Meteorological Data}

Meteorological data are reported in Figure 1. The averages of THI during daytime were 2.3 to 6.3 units higher in the exposed areas than in the protected areas. In contrast, during nighttime, averages of THI were 5.4 to 7.8 units higher in the protected areas than in the exposed areas.

In the exposed areas, the THI values were near 77 , on average, during daytime and 63 during nighttime. In the protected areas, THI was 73 , on average, during daytime and was more than 6 points higher than in the exposed areas during nighttime.

\section{Milk Yield and Quality}

Flaxseed supplementation increased milk yield and fat, protein, and casein yields $(P<0.001$; Table 3$)$. Milk and fat yields were affected by time of sampling and the interaction of diet $\times$ time of sampling $(P<$ 0.001 and $P<0.05$, respectively); flaxseed increased milk and fat yields starting from wk 2 of milk sampling and thereafter (Figure 2). Flaxseed supplementation increased fat and lactose contents of milk $(P<0.01$ and $P<0.001$, respectively), whereas exposure to solar radiation resulted in increased contents of fat and casein $(P<0.05)$ and lactose $(P<0.001)$ in milk. Fat and lactose contents were affected by time of sampling with fluctuations connected to milk yield $(P<0.001)$.

Flaxseed supplementation shortened milk clotting time (17.55 vs. $15.90 \mathrm{~min} \pm 0.47)$, and increased curd firmness ( 51.50 vs. $56.14 \mathrm{~mm} \pm 1.46)$ and milk coagulation index ( 3.25 vs. $3.63 \pm 0.13 ; P<0.05)$, with EXP-F milk displaying the best coagulation parameters (Table 4). Flaxseed supplementation decreased SCC of milk by about $57 \%$, with the lowest cell count being found in EXP-F ewes $(P<0.001)$.
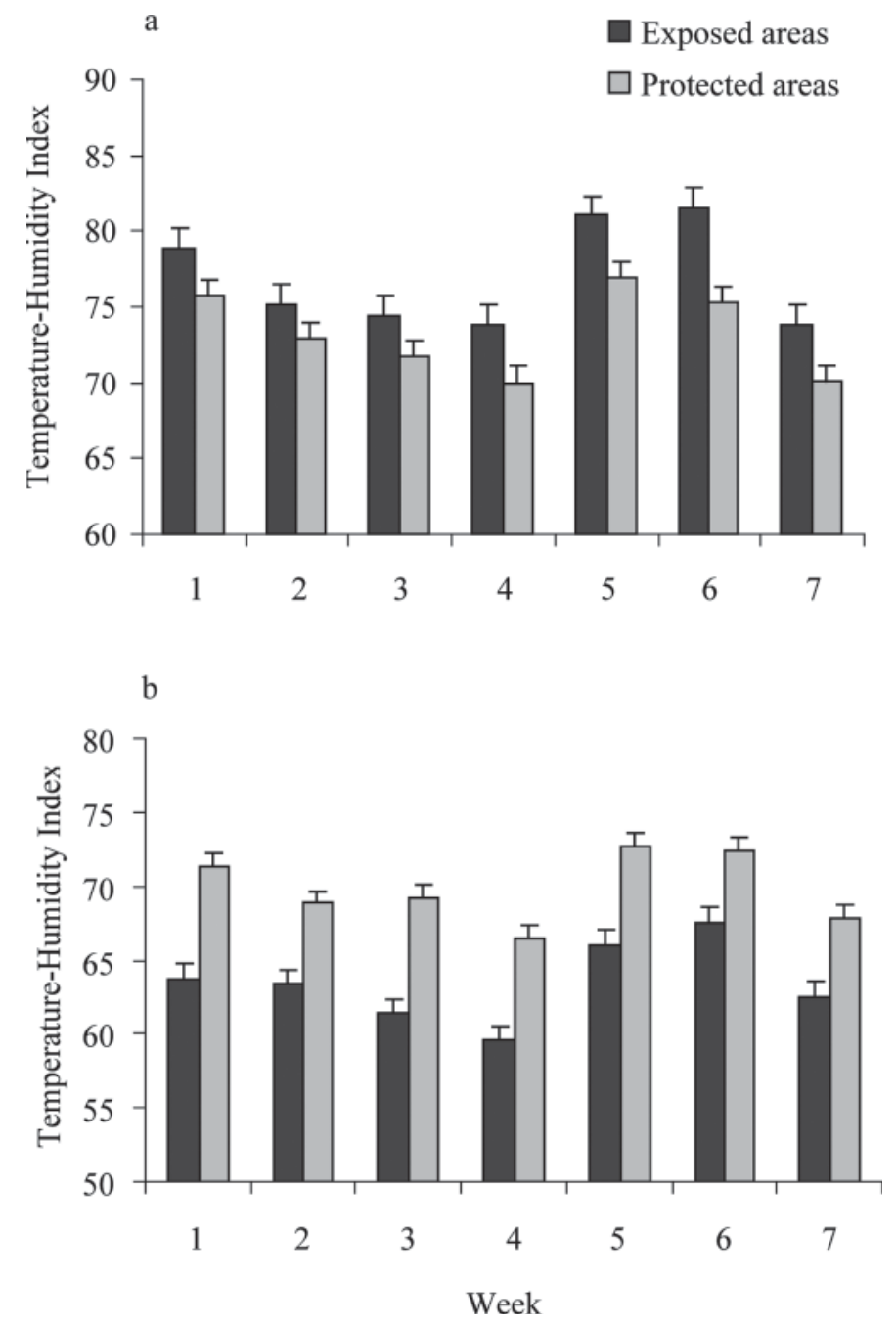

Figure 1. Means $\pm \mathrm{SD}$ of temperature-humidity index (THI) in exposed and protected areas measured during (a) daytime (0800 to $2000 \mathrm{~h}$ ) and (b) nighttime (2000 to $0800 \mathrm{~h}$ ).

\section{Milk Fatty Acids Composition}

The fatty acid composition of milk is reported in Table 5. A decrease in SFA from C6:0 to C16:0 $(P<$ 0.001) was observed in milk from flaxseed-supplemented ewes. Flaxseed supplementation also led to a decrease of C17:0 $(P<0.01)$ and $\mathrm{C} 17: 1(P<0.001)$. An effect of time was observed because the aforementioned fatty acids began to decrease in the flaxseed-supplemented groups starting on d 23 of the experiment. Exposure to solar radiation increased C16:0 (23.31 vs. $24.26 \pm$ $0.25 \mathrm{~g} / 100 \mathrm{~g}$ of total fatty acids; $P<0.01$ ), and the highest C16:0 content was observed in EXP-C milk ( $P$ $<0.05$ ). In contrast, C18:0 (stearic acid) was higher in milk from ewes receiving flaxseed supplementation 
Table 3. Milk yield and composition in ewes when exposed to solar radiation and fed control diet (EXP-C), exposed to solar radiation and fed flaxseed (EXP-F), protected from solar radiation and fed control diet (PRO-C), and protected from solar radiation and fed flaxseed (PRO-F)

\begin{tabular}{|c|c|c|c|c|c|c|c|c|}
\hline \multirow[b]{2}{*}{ Item } & \multicolumn{4}{|c|}{ Treatment } & \multirow[b]{2}{*}{ SEM } & \multicolumn{3}{|c|}{ Effects, $P$-value ${ }^{1}$} \\
\hline & EXP-C & EXP-F & PRO-C & PRO-F & & $\mathrm{SR}$ & Diet & Time \\
\hline \multicolumn{9}{|l|}{ Yield, g/d } \\
\hline Fat & $41.82^{\mathrm{b}}$ & $50.72^{\mathrm{a}}$ & $41.66^{\mathrm{b}}$ & $51.39^{\mathrm{a}}$ & 1.02 & NS & $* * *$ & $* *$ \\
\hline Protein & $34.51^{\mathrm{b}}$ & $40.21^{\mathrm{a}}$ & $35.29^{\mathrm{b}}$ & $41.03^{\mathrm{a}}$ & 0.86 & NS & $* * *$ & $* * *$ \\
\hline Casein & $27.27^{\mathrm{b}}$ & $32.34^{\mathrm{a}}$ & $27.11^{\mathrm{b}}$ & $32.53^{\mathrm{a}}$ & 0.37 & NS & $* * *$ & $* * *$ \\
\hline Protein & 5.81 & 5.66 & 5.69 & 5.66 & 0.16 & NS & NS & NS \\
\hline Casein & $4.59^{\mathrm{a}}$ & $4.56^{\mathrm{a}}$ & $4.36^{\mathrm{b}}$ & $4.50^{\mathrm{ab}}$ & 0.14 & * & NS & NS \\
\hline Lactose & $4.64^{\mathrm{b}}$ & $4.86^{\mathrm{a}}$ & $4.33^{\mathrm{c}}$ & $4.66^{\mathrm{b}}$ & 0.07 & $* * *$ & $* * *$ & $* * *$ \\
\hline
\end{tabular}

${ }^{\mathrm{a}-\mathrm{C}}$ Means within a row followed by different letters are significantly different at $P<0.05$.

${ }^{1} \mathrm{SR}=$ solar radiation; Time $=$ time of sampling.

${ }^{*} P<0.05 ;{ }^{* *} P<0.01 ;{ }^{* * *} P<0.001$.

than in nonsupplemented ewes $(P<0.001)$, starting on d 23 of the trial $(P<0.001)$. As a result, the diet based on flaxseed supplementation reduced the SFA content of milk $(P<0.001)$, starting on d 23 of the experiment $(P<0.05$, Figure 3$)$.
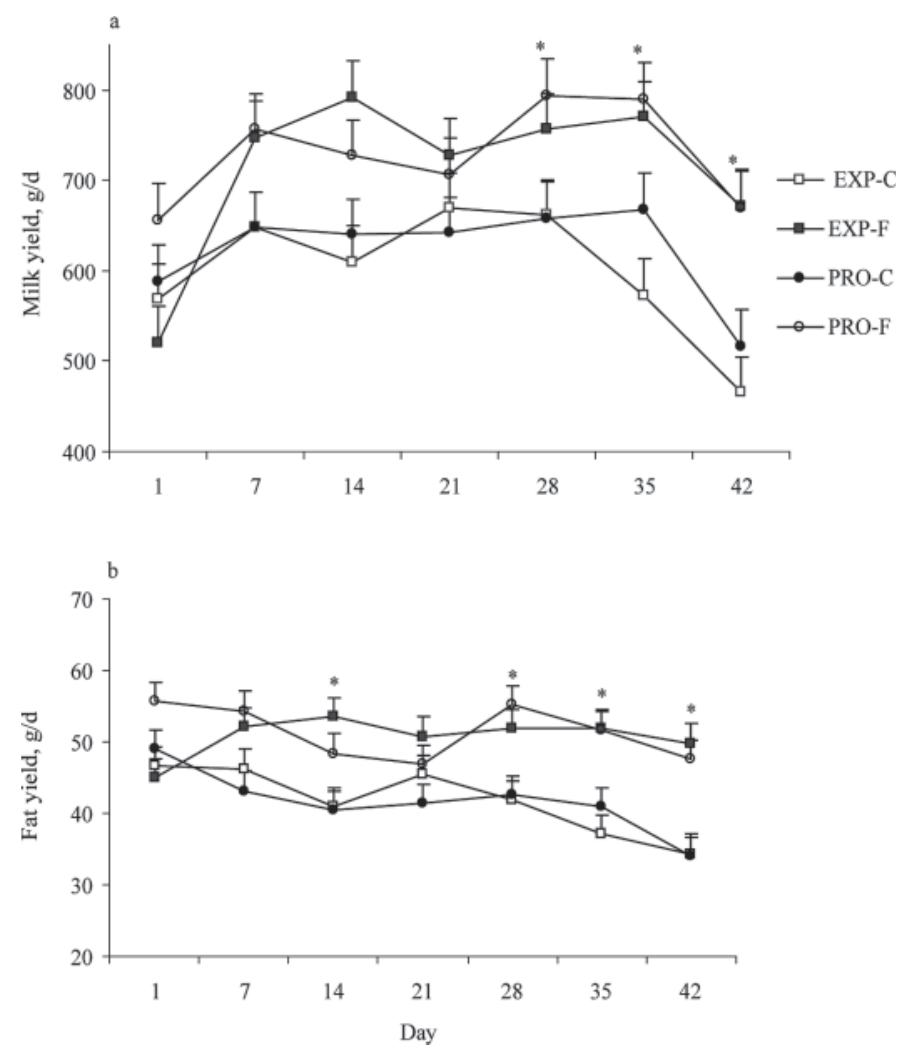

Figure 2. Temporal changes in milk and fat yield in ewes when exposed to solar radiation and fed control diet (EXP-C), exposed to solar radiation and fed flaxseed (EXP-F), protected from solar radiation and fed control diet (PRO-C), or protected from solar radiation and fed flaxseed (PRO-F). Differences between the groups at each time point are represented by $*(P<0.05)$.
As expected, the diet supplemented with flaxseed influenced the levels of C18:1 trans-9, C18:1 trans-11, and $\mathrm{C} 18: 1$ cis-9 in milk $(P<0.001)$. In addition, milk from EXP ewes showed lower average C18:1 trans-9 than milk from PRO ewes (0.38 vs. $0.43 \pm 0.02 \mathrm{~g} / 100$ $\mathrm{g}$ of total fatty acids; $P<0.05)$. The $\mathrm{C} 18: 1$ trans -11 (VA) content in milk was lower in EXP than in PRO groups at the beginning of the experiment. Vaccenic acid content in milk from supplemented ewes increased starting on d 23 of the trial (Figure $4 ; \mathrm{P}<0.001$ ).

The total MUFA content of milk from ewes fed flaxseed also showed a significant increase $(P<0.001$, Figure 3$)$ starting from d $23(P<0.001)$. Flaxseed supplementation resulted in increased levels of PUFA $(P$ $<0.001)$ starting from d 23 in the exposed groups. Fat supplementation influenced SCFA, MCFA, and LCFA contents of milk $(P<0.001)$ by decreasing SCFA and MCFA and increasing LCFA content of milk. In addition, milk from EXP-C had higher content of MCFA than milk from PRO-C (Figure 3).

Flaxseed supplementation increased C18:2 trans9,trans-12 and C18:2 cis-9,trans-11 contents of milk ( $P$ $<0.001$ ). At the beginning of the experiment (Figure 4), the C18:2 cis-9,trans-11 content was higher in milk of ewes protected from solar radiation $(P<0.01)$, aside from flaxseed supplementation; subsequently, on d 23, the flaxseed-supplemented groups showed an increase of C18:2 cis-9,trans-11. On average, flaxseed supplementation led to an increase in C18:2 cis-9,trans-11 of about $80 \%$ in milk from ewes exposed to solar radiation and of $63 \%$ in milk of ewes protected from solar radiation. Consequently, an increase of the total content of CLA isomers in groups subjected to the flaxseed diet (EXP-F, PRO-F) was observed, starting on d 23 of the trial (Figure 4). Milk from EXP-F ewes showed, on average, a $57 \%$ higher content of CLA isomers than 
Table 4. pH, renneting parameters, and SCC in milk of ewes when exposed to solar radiation and fed control diet (EXP-C), exposed to solar radiation and fed flaxseed (EXP-F), protected from solar radiation and fed control diet (PRO-C), and protected from solar radiation and fed flaxseed (PRO-F)

\begin{tabular}{|c|c|c|c|c|c|c|c|c|}
\hline \multirow[b]{2}{*}{ Item } & \multicolumn{4}{|c|}{ Treatment } & \multirow[b]{2}{*}{ SEM } & \multicolumn{3}{|c|}{ Effects, $P$-value ${ }^{1}$} \\
\hline & EXP-C & EXP-F & PRO-C & PRO-F & & $\mathrm{SR}$ & Diet & Time \\
\hline $\mathrm{pH}$ & 6.49 & 6.47 & 6.51 & 6.51 & 0.01 & $\mathrm{NS}$ & NS & $* * *$ \\
\hline Clotting time, $\min$ & $17.44^{\mathrm{a}}$ & $14.51^{\mathrm{b}}$ & $17.66^{\mathrm{a}}$ & $17.29^{\mathrm{a}}$ & 0.66 & $*$ & $*$ & NS \\
\hline Rate of clot formation, $\min$ & 1.27 & 1.53 & 1.40 & 1.43 & 0.15 & $\mathrm{NS}$ & NS & NS \\
\hline Clot firmness, $\mathrm{mm}$ & $51.96^{\mathrm{b}}$ & $59.75^{\mathrm{a}}$ & $51.04^{\mathrm{b}}$ & $52.52^{\mathrm{b}}$ & 2.07 & $*$ & $*$ & NS \\
\hline $\mathrm{CoI}^{2}$ & $3.29^{\mathrm{b}}$ & $4.05^{\mathrm{a}}$ & $3.21^{\mathrm{b}}$ & $3.22^{\mathrm{b}}$ & 0.44 & * & * & NS \\
\hline $\mathrm{SCC}, \times 10^{3}$ cells $/ \mathrm{mL}$ & $957.49^{\mathrm{a}}$ & $354.46^{\mathrm{c}}$ & $814.14^{\mathrm{a}}$ & $655.99^{\mathrm{b}}$ & 52.91 & NS & $* * *$ & $* *$ \\
\hline
\end{tabular}

${ }^{\mathrm{a}-\mathrm{c}}$ Means within a row followed by different letters are significantly different at $P<0.05$.

${ }^{1} \mathrm{SR}=$ solar radiation; Time $=$ time of sampling.

${ }^{2}$ Milk coagulating index $(\mathrm{CoI})=$ clot firmness to clotting time + rate of clot formation ratio.

${ }^{*} P<0.05 ;{ }^{* *} P<0.01 ;{ }^{* * *} P<0.001$.

Table 5. Least square means of milk fatty acid composition ( $\mathrm{g} / 100 \mathrm{~g}$ of total fatty acids) of ewes when exposed to solar radiation and fed control diet (EXP-C), exposed to solar radiation and fed flaxseed (EXP-F), protected from solar radiation and fed control diet (PRO-C), and protected from solar radiation and fed flaxseed (PRO-F)

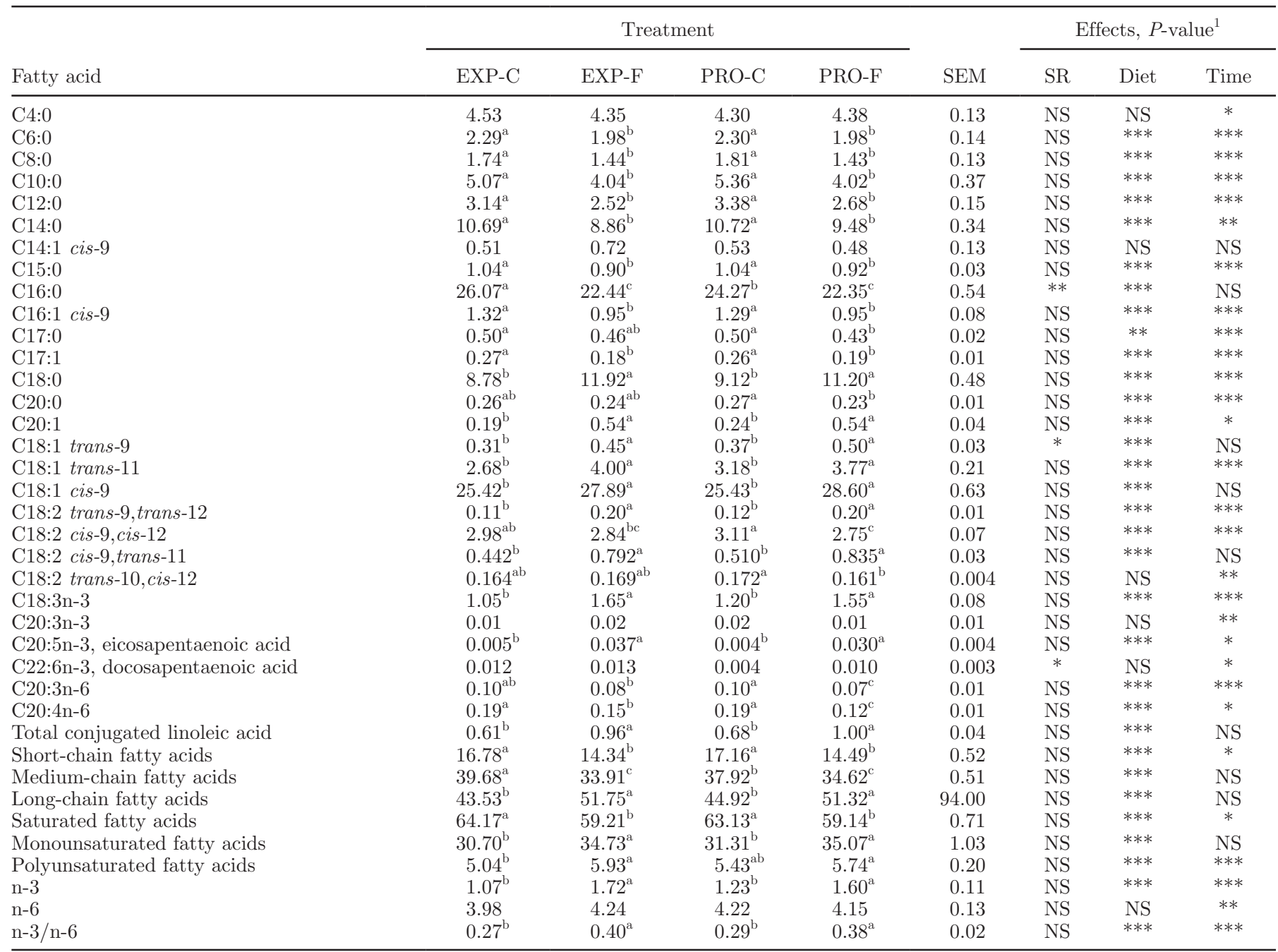

${ }^{\mathrm{a}-\mathrm{c}}$ Means within a row followed by different letters are significantly different at $P<0.05$.

${ }^{1} \mathrm{SR}=$ solar radiation; Time $=$ time of sampling.

${ }^{*} P<0.05 ;{ }^{* *} P<0.01 ;{ }^{* * *} P<0.001$. 

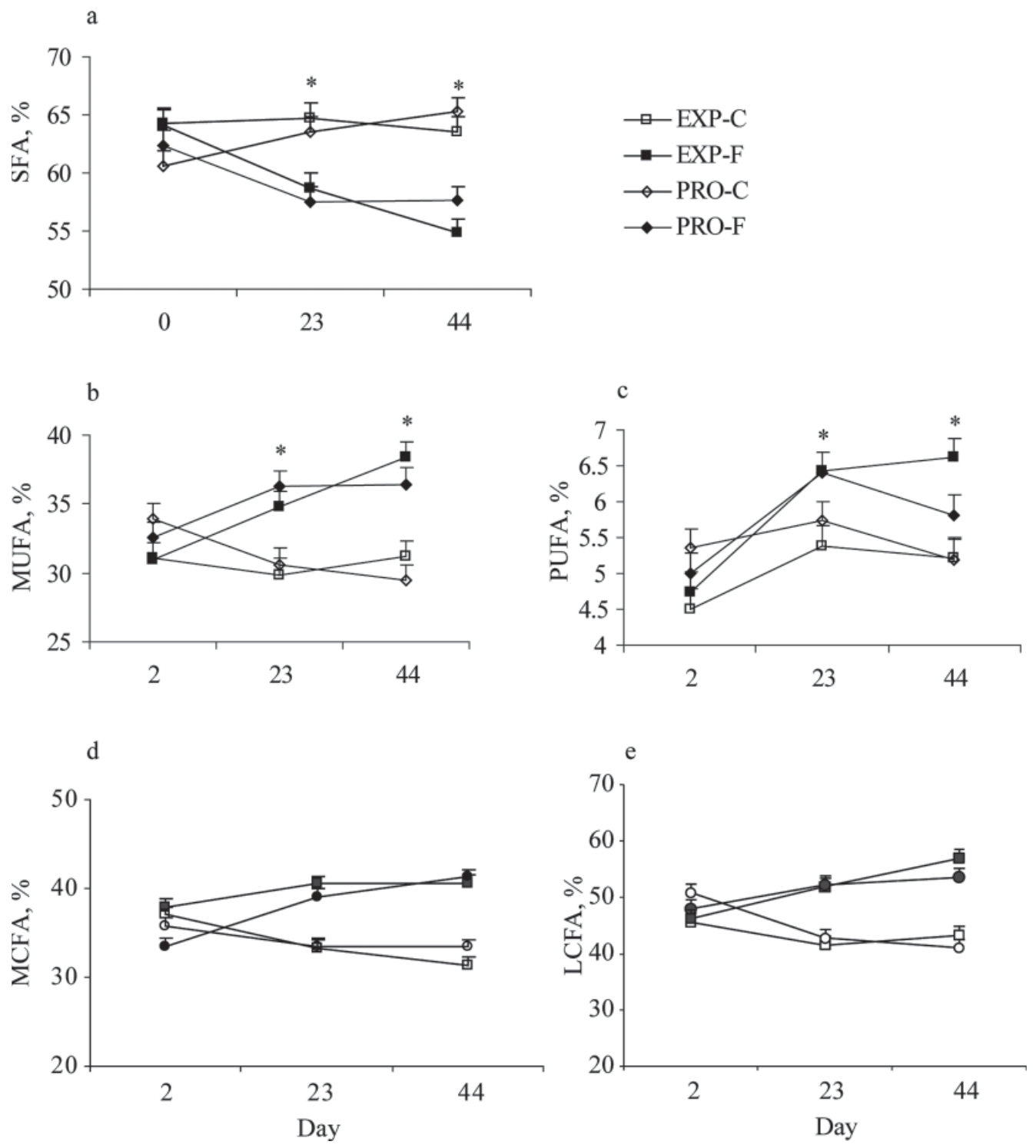

Figure 3. Temporal changes in saturated fatty acids (SFA), monounsaturated fatty acids (MUFA), polyunsaturated fatty acids (PUFA), medium-chain fatty acids (MCFA), and long-chain fatty acids (LCFA) content in ewes when exposed to solar radiation and fed control diet (EXP-C), exposed to solar radiation and fed flaxseed (EXP-F), protected from solar radiation and fed control diet (PRO-C), protected from solar radiation and fed flaxseed (PRO-F). Differences between the groups at each time point are represented by $*(P<0.05)$.

EXP-C milk, and PRO-F milk displayed a $47 \%$ higher content of CLA than PRO-C milk.

Flaxseed supplementation also positively influenced the $\alpha$-linolenic acid content of milk $(\mathrm{C} 18: 3 \mathrm{n}-3 ; P<$ $0.001)$, which began to increase in the supplemented groups starting from d $23(P<0.001$; Figure 4$)$. The diet based on flaxseed also resulted in an increase of eicosapentaenoic acid (C20:5n-3; $P<0.001)$. As a result, milk from supplemented groups showed an increase in n-3 PUFA content $(P<0.001)$. In particular, increases in n-3 PUFA content of about $60 \%$ in milk from EXP-F compared with EXP-C ewes, and of $30 \%$ in milk from $\mathrm{PRO}-\mathrm{F}$ compared with PRO-C ewes were observed. The increase of milk n-3 PUFA content in the flaxseed-supplemented groups also resulted in a higher n-3/n-6 ratio in EXP-F and PRO-F milk compared with EXP-C and PRO-C milk $(P<0.001)$.

On average, flaxseed supplementation positively influenced the $\mathrm{C} 18: 2$ cis- 9 , trans-11/C18:1 trans- $11 \Delta^{9}$-desaturase index $(P<0.001$; Table 6$)$, starting on d 23 of the experiment $(P<0.001)$, in correspondence with the highest C18:2 cis-9,trans-11 content of milk from 

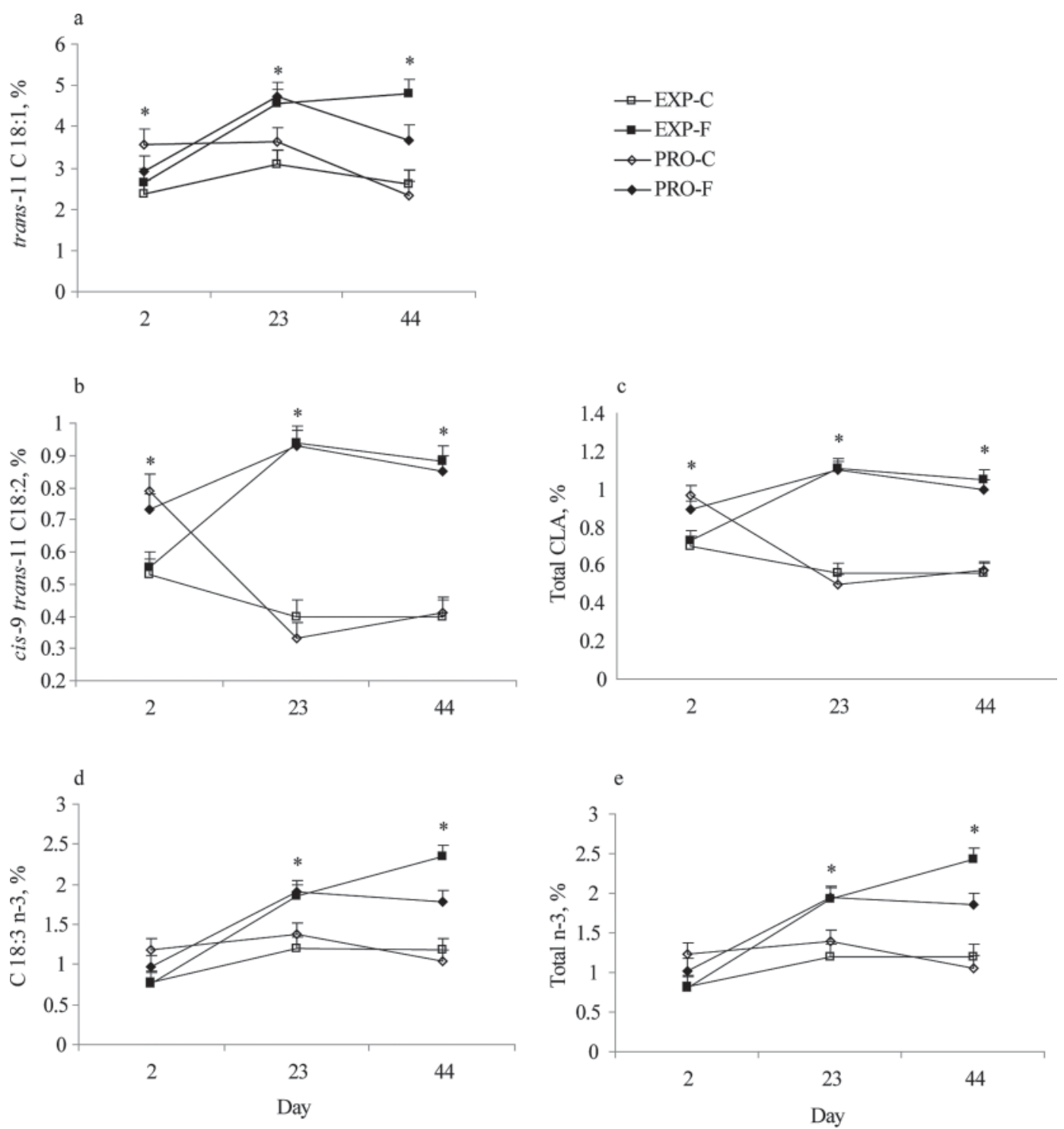

Figure 4. Temporal changes in C18:1 trans-11, C18:2 cis-9,trans-11, total conjugated linoleic acid (CLA), C18:3 n-3, and total n-3 polyunsaturated fatty acids (PUFA) in ewes when exposed to solar radiation and fed control diet (EXP-C), exposed to solar radiation and fed flaxseed (EXP-F), protected from solar radiation and fed control diet (PRO-C), protected from solar radiation and fed flaxseed (PRO-F). Differences between the groups at each time point are represented by * $(P<0.05)$.

EXP-F and PRO-F ewes. Flaxseed supplementation decreased the atherogenic and thrombogenic indices of milk $(P<0.001)$.

\section{DISCUSSION}

Sheep are thought to be among the most resistant ruminants to climatic extremes (being less affected by extremes), especially to high ambient temperatures. Experiments conducted on Comisana ewes by Sevi et al. (2001, 2002) demonstrated a reduction in milk yield after exposure to average daily temperatures of $35^{\circ} \mathrm{C}$, even for short periods, or after prolonged ewe exposure to mean ambient temperatures of $30^{\circ} \mathrm{C}$. Sarda ewes are highly sensitive to high temperatures. Peana et al. (2007) found that in Sarda ewes, milk yield could be reduced by $15 \%$ if the maximum ambient temperatures are higher than 21 to $24^{\circ} \mathrm{C}$, and by $20 \%$ if the minimum temperature changed from 9 to $12^{\circ} \mathrm{C}$ to 18 to $21^{\circ} \mathrm{C}$. In light of previous findings, we can hypothesize that the effect of higher maximum temperatures on the milk yield of ewes exposed to solar radiation during daytime was counterbalanced by the effect of higher minimum temperatures acting on protected ewes during nighttime. This resulted in failure to find differences in milk yield between shaded and nonshaded ewes. In addition, 
Table 6. Least square means of desaturase and nutritional indexes of milk in ewes when exposed to solar radiation and fed control diet (EXP-C), exposed to solar radiation and fed flaxseed (EXP-F), protected from solar radiation and fed control diet (PRO-C),and protected from solar radiation and fed flaxseed $(\mathrm{PRO}-\mathrm{F})$

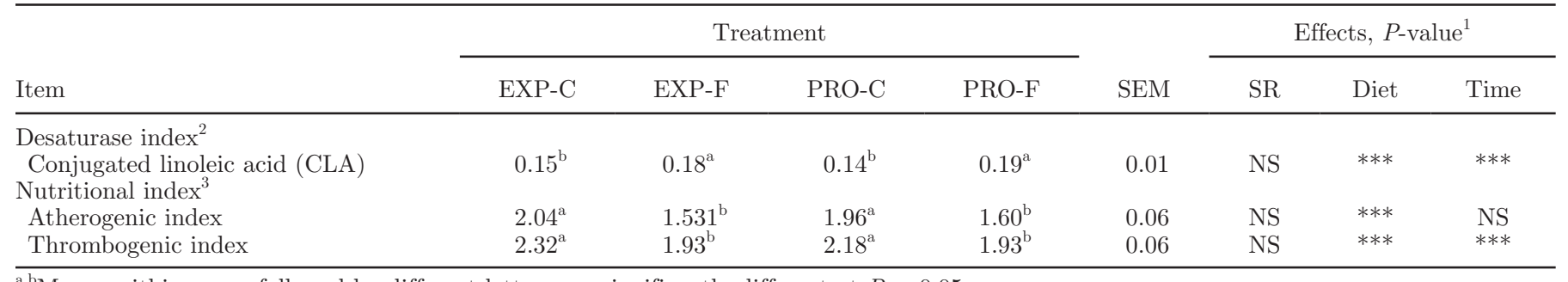

${ }^{\mathrm{a}, \mathrm{b}}$ Means within a row followed by different letters are significantly different at $P<0.05$.

${ }^{1} \mathrm{SR}=$ solar radiation; Time $=$ time of sampling.

${ }^{2}$ CLA desaturase index was calculated as [cis-9, trans-11 CLA $] /[$ cis-9, trans-11 CLA + trans-11 18:1]; Kelsey et al. (2003).

${ }^{3}$ Atherogenic and thrombogenic indexes were calculated using Ulbricht and Southgate (1991) formulas.

$* * * P<0.001$.

a physiological decrease in milk yield in ewes occurs during summer with late lactation, which could completely or partly hide the negative effect of high temperatures on milk production.

Flaxseed supplementation increased milk yields by about $18 \%$ in both exposed and protected ewes. In particular, in the exposed group, milk yield was higher at the end of the experiment than at the beginning. Our results are in line with those obtained by Zhang et al. (2006a,b), whereas flaxseed supplementation had no effects on milk yield in cows (Caroprese et al., 2010). The increase in milk yield observed in supplemented groups is not easy to explain, given that control and flaxseedsupplemented diets had very similar $\mathrm{NE}_{\mathrm{L}}$, whereas in the Zhang et al. (2006a,b) experiments, the increase in ewe milk yield reflected the higher energy content of the flaxseed-supplemented diet. The possibility that increased lactose resulted in high levels of production in ewes receiving flaxseed cannot be excluded.

The increase in milk yield in flaxseed-supplemented ewes led to increases in fat, protein, and casein yields. Flaxseed in the diet increased fat content of milk; the effects of lipid supplementation on milk fat are controversial depending on the type of supplemented fat, the level of supplementation, and the species. In goat and sheep milk, no effects of extruded linseed were found on fat content (Nudda et al., 2006; Gómez-Cortés et al., 2009). In previous experiments, the supplementation of $8 \%$ rumen-protected fat to sheep or whole flaxseed to cows contributed to increase the fat content of milk (Rotunno et al., 1998; Caroprese et al., 2010). The increase in fat and casein contents of milk observed in EXP-C ewes can be attributed to the reduction of milk yield registered in that group. Dietary fat usually decreases milk protein synthesis because of a reduction in amino acid availability to the mammary gland (Rotunno et al., 1998; Pulina et al., 2006). Only a few studies have reported the effects of supplemental fat to sheep diet on milk protein composition (Goulas et al., 2003; Zhang et al., 2006a,b). In our study, flaxseed supplementation had a positive effect on casein content of milk, which was associated with better rheological properties of milk from ewes fed flaxseed. It is well known that milk coagulation is strictly connected to milk composition and SCC (Albenzio et al., 2004). Milk from ewes fed flaxseed was characterized by improved milk composition and lower SCC, resulting in better coagulation properties. Few studies focused on the effects of direct solar radiation or fat supplementation on milk SCC (Sevi et al., 2001; Liu et al., 2008; Caroprese et al., 2010) and did not show a direct effect of both factors on SCC.

Different dietary strategies to improve the fatty acid profile of ewe milk have been assessed, with an improvement of the saturated to unsaturated fatty acid ratio (Rotunno et al., 1998; Zhang et al., 2006a,b). The administration of an appropriate dietary fat supplement can be effective in increasing the content of unsaturated fatty acids of ewe milk especially in late lactation, when a reduction of mobilization of body reserves for milk synthesis occurs (Rotunno et al., 1998). Accordingly, in the present study, flaxseed supplementation increased both the MUFA and PUFA contents of sheep milk, together with a reduction of SFA, SCFA, and MCFA. The increase in PUFA in the mammary gland could explain the reduction of both SCFA and MCFA in milk from flaxseed-supplemented ewes; previous findings confirmed that PUFA compete for esterification with SCFA and MCFA synthesized in the mammary gland, causing a feedback inhibition of lipogenic enzymes (Gómez-Cortés et al., 2008, 2009). The decrease of C16:0 observed in the milk from supplemented ewes can be ascribed both to the inhibition of its synthesis and to the reduced $\mathrm{C} 16: 0$ content in flaxseed compared with 
the C16:0 content of vetch and oat hay and concentrate. In addition, in a previous experiment, an increase of the proportions of $\mathrm{C} 12: 0, \mathrm{C} 14: 0$, and $\mathrm{C} 16: 0$ fatty acids in milk from ewes exposed to direct solar radiation during summer was observed (Sevi et al., 2002).

Diet is responsible for C18 fatty acid content in milk because the mammary gland enzymatic systems cannot extend the carbon chain from C16 to C18. Therefore, a major concentration of $\mathrm{C} 18$ fatty acids, especially in milk of ewes fed a flaxseed supplement, is due to the high content of C18:3n-3 in such seed (Zhang et al., 2006a,b). The high C18:0 concentration observed in milk of ewes subjected to flaxseed supplementation is the result of the biohydrogenation of unsaturated $\mathrm{C} 18$ fatty acids in the rumen (Lock and Garnsworthy, 2003). Generally, high values in milk C18:1 fatty acids arise from ruminal biohydrogenation of $\mathrm{C} 18: 2$ and C18:3 fatty acids, and from desaturation of C18:0 in the mammary gland by the action of the $\Delta^{9}$-desaturase enzyme (Dhiman et al., 2000). The C18:1 cis-9 (oleic acid) in milk is a product arising from the isomerization of blood C18:0 (stearic acid) by $\Delta^{9}$-desaturase activity in the mammary gland (Gómez-Cortés et al., 2009), whereas VA is produced in the rumen and then absorbed by the gut to be transported in the mammary gland, where it is used for endogenous synthesis of RA, through stearoylCoA desaturase activity (Luna et al., 2008b). Flaxseed supplementation increased the content of milk VA by about $50 \%$ in the ewes exposed to solar radiation and by $18 \%$ in the ewes protected from solar radiation. The importance of increasing VA in milk arises from the observation that VA is the substrate for the production of RA, not only in the mammary gland of ruminant but also in muscle and adipose tissues in humans (Bauman et al., 2006). The accumulation of VA resulted in increased concentrations of RA in milk from ewes supplemented with flaxseed.

Sevi et al. (2002) found a reduction of both MUFA and PUFA and an increase in C12:0 to C16:0 fatty acids in milk from ewes exposed to direct solar radiation compared with shaded ewes during summer. Accordingly, at the beginning of this study, the content of MCFA was higher, and the contents of LCFA, some PUFA, such as C18:1 trans-11 and C18:2 cis-9,trans-11, and total CLA were lower in milk from ewes exposed to solar radiation. High ambient temperature can reduce the rate of digesta passage in the rumen (Silanikove, 1992), thus allowing an extensive hydrogenation of unsaturated fatty acids, and a consequent reduction of MUFA and PUFA in milk. Subsequently, the administration of flaxseed changed the fatty acid composition during the experiment, with higher content of VA, RA, and of total CLA in milk from supplemented ewes, apart from the direct exposure to solar radiation. The administration of whole flaxseed to heat-stressed cows in a previous experiment did not result in a subsequent increase in milk C18:3 (Caroprese et al., 2010), whereas in the present experiment an increase of $\mathrm{C} 18: 3$ in milk from ewes fed whole flaxseed was observed, according to Zhang et al. (2006a,b). As a consequence, different utilization of whole flaxseed in the rumen and then in the mammary gland has to be hypothesized in cows and sheep when they are subjected to heat stress. The fatty acid profile of sheep milk is mainly influenced by diet, even if other factors may account for variations of milk fatty acid profile, such as stage of lactation, parity, and season (De La Fuente et al., 2009). In particular, the reduction of $\mathrm{C} 18: 3$ availability in the diet during summer resulted in a seasonal decrease of C18:3, VA, and CLA content in milk of Sarda sheep (Nudda et al., 2005). Flaxseed supplementation was effective in reducing the adverse effects of both heat stress and the advancement of lactation on milk fatty acids composition, resulting in evident increases in milk contents of VA, RA, total CLA, and C18:3n-3, starting from d 23 of the experiment until the end of the experiment. In milk from ewes fed flaxseed, contents of VA, RA, and total CLA increased during the experiment, whereas those of C18:3n-3 and total PUFA n-3 fatty acids were higher at the end than at the beginning of the experiment in milk from both EXP-F and PRO-F. The persistency of the positive effects of flaxseed supplementation on milk VA, RA, and total CLA in this study confirmed previous findings by Gómez-Cortés et al. (2009), whereas the evolution of C18:3n-3 suggested further investigation on the use of whole flaxseed to increase the content of PUFA n-3 in milk from lactating ewes in advanced stages of lactation. The increases of VA, RA, and total CLA were more marked in milk from ewes exposed to solar radiation than in milk from shaded ewes, suggesting the advantage of using whole flaxseed supplement to improve the fatty acid profile in milk of ewes subjected to high ambient temperatures.

The decrease of C12:0, C14:0, and C16:0 fatty acids caused a consequent reduction of atherogenic and thrombogenic indices in milk of ewes subjected to flaxseed supplementation. Milk fat with high atherogenic index values has detrimental effects on human health. It is known that in the human diet, SFA contributes to coronary diseases, whereas the unsaturated fatty acids, including CLA (rumenic acid), MUFA (in particular, oleic acid) and PUFA, have a protective effect against cardiovascular diseases (Williams, 2000). As it has been demonstrated that fatty acid composition of sheep cheese is dependent on the fatty acid composition of raw milk (Nudda et al., 2006), the improvement of fatty acid profile in milk can result in naturally enriched dairy products. 


\section{CONCLUSIONS}

Protection from solar radiation under high ambient temperatures did not increase the yield and improve the composition of ewe milk. Nevertheless, milk from ewes exposed to solar radiation showed a worsening of fatty acid profile in terms of decreased LCFA and PUFA content, and in particular, decreased VA, RA, and total CLA contents. Flaxseed supplementation, instead, had several positive effects on the yield and quality of ewe milk. Indeed, it increased the yield and composition of milk, leading to a reduction of SCC, an increase of fat content, and better coagulation properties of milk. Sheep farmers can benefit from enhanced ewe milk yield in summer because at that time dairy factories typically stop collecting milk from sheep farms as a result of decreased milk production and deteriorating coagulation behavior. Moreover, flaxseed supplementation resulted in an enhanced fatty acid profile of milk, as demonstrated by the increase in PUFA, VA, RA, total CLA, and n-3 PUFA, and the decrease in SFA, SCFA, and MCFA. This finding is of great interest both because consumer demand for dairy products naturally enriched in healthy components has grown and because the fatty acid profile of ewe milk undergoes a marked worsening during summer.

\section{REFERENCES}

Albenzio, M., M. Caroprese, A. Santillo, R. Marino, L. Taibi, and A. Sevi. 2004. Effects of somatic cell count and stage of lactation on the plasmin activity and cheese-making properties of ewe milk. J. Dairy Sci. 87:533-542.

AOAC. 1990. Official Methods of Analysis. 15th ed. Association of Official Analytical Chemists, Arlington, VA.

Ardvisson, K., A. M. Gustavsson, and K. Martinsson. 2009. Fatty acids in forages: A comparison of different pre-treatments prior to analysis. Anim. Feed Sci. Technol. 151:143-152.

Bauman, D. E., A. L. Lock, B. A. Corl, C. Ip, A. M. Salter, and P. W. Parodi. 2006. Milk fatty acids and human health: potential role of conjugated linoleic acid and trans fatty acids. Pages 529-561 in Ruminant Physiology. K. Sejrsen, T. Hvelplund and M. O Nielsen, ed. Wageningen Academic Publishers, Wageningen, the Netherlands.

Caroprese, M., A. Marzano, G. Entrican, S. Wattegedera, M. Albenzio, and A. Sevi. 2009. Immune response of cows fed polyunsaturated fatty acids under high ambient temperatures. J. Dairy Sci. 92:2796-2803.

Caroprese, M., A. Marzano, R. Marino, G. Gliatta, A. Muscio, and A. Sevi. 2010. Flaxseed supplementation improves fatty acid profile of cow milk. J. Dairy Sci. 93:2580-2588.

De La Fuente, L. F., E. Barbosa, J. A. Carriedo, C. Gonzalo, R. Arenas, J. M. Fresno, and F. San Primitivo. 2009. Factors influencing variation of fatty acid content in ovine milk. J. Dairy Sci. 92:3791-3799.

Dhiman, T. R., L. D. Satter, M. W. Pariza, M. P. Galli, K. Albridht, and M. X. Tolosa. 2000. Conjugated linoleic acid (CLA) content of milk from cows offered diets rich in linoleic and linolenic acid. J. Dairy Sci. 83:1016-1027.

Drackley, J. K., T. M. Cicela, and D. W. LaCount. 2003. Responses of primiparous and multiparous Holstein cows to additional energy from fat or concentrate during summer. J. Dairy Sci. 86:13061314.

Gómez-Cortés, P., A. Bach, P. Luna, M. Juárez, and M. A. de la Fuente. 2009. Effects of extruded linseed supplementation on n-3 fatty acids and conjugated linoleic acid in milk and cheese from ewes. J. Dairy Sci. 92:4122-4134.

Gómez-Cortés, P., P. Frutos, A. R. Mantecón, M. Juárez, M. A. de la Fuente, and G. Hervás. 2008. Addition of olive oil to dairy ewe diet: Effect on milk fatty acid profile and animal performance. J. Dairy Sci. 91:3119-3127.

Goulas, C., G. Zervas, and G. Papadopoulos. 2003. Effect of dietary animal fat and methionine on dairy ewes milk yield and milk composition. Anim. Feed Sci. Technol. 105:43-54.

IDF. 1990. Determination of milk fat, protein \& lactose content-Guide for the operation of mid-infrared instruments. FIL-IDF Standard no. 141B. International Dairy Federation, Brussels, Belgium.

IDF. 1995. Enumeration of somatic cells. FIL-IDF Standard no. 148A. International Dairy Federation, Brussels, Belgium.

ISO-IDF. 2002. Milk fat-Preparation of fatty acid methyl esters. International Standard ISO 15884-IDF 182:2002. International Dairy Federation, Brussels, Belgium.

Kelly, C. F., and T. E. Bond. 1971. Bioclimatic Factors and Their Measurement: A Guide to Environmental Research on Animals. Natl. Acad. Sci., Washington, DC.

Kelsey, J. A., B. A. Corl, R. J. Collier, and D. E. Bauman. 2003 The effect of breed, parity, and stage of lactation on conjugated linoleic acid (CLA) in milk fat from dairy cows. J. Dairy Sci. 86:2588-2597.

Liu, Z. L., P. Chen, J. M. Li, S. B. Lin, D. M. Wang, L. P. Zhu, and D. P. Yang. 2008. Conjugated linoleic acids (CLA) moderate negative responses of heat-stressed cows. Livest. Sci. 118:255-261.

Lock, A. L., and P. C. Garnsworthy. 2003. Seasonal variation in milk conjugated linoleic acid and $\Delta^{9}$-desaturase in dairy cows. Livest. Prod. Sci. 79:47-59.

Luna, P., A. Bach, M. Juárez, and M. A. de la Fuente. 2008b. Effect of a diet enriched in whole linseed and sunflower oil and goat milk fatty acid composition and conjugated linoleic acid isomer profile. J. Dairy Sci. 91:20-28.

Luna, P., M. Juárez, and M. A. de la Fuente. 2005. Validation of a rapid milk fat separation method to determine the fatty acid profile by gas chromatography. J. Dairy Sci. 88:3377-3381.

McGuire, M. A., and M. K. McGuire. 2000. Conjugated linoleic acid (CLA): A ruminant fatty acid with beneficial effects on human health. J. Anim. Sci. 77:1-8.

NRC (National Research Council). 2001. Nutrient Requirements of Dairy Cattle. 7th rev. ed. Natl. Acad. Sci., Washington, DC.

Nudda, A., G. Battacone, M. G. Usai, S. Fancellu, and G. Pulina 2006. Supplementation with extruded linseed cake affects concentrations of conjugated linoleic acid and vaccenic acid in goat milk. J. Dairy Sci. 89:277-282.

Nudda, A., M. A. McGuire, G. Battacone, and G. Pulina. 2005. Seasonal variation in conjugated linoleic acid and vaccenic acid in milk fat of sheep and its transfer to cheese and ricotta. J. Dairy Sci. 88:1311-1319.

Peana, I., G. Fois, and A. Cannas. 2007. Effects of heat stress and diet on milk production and feed and energy intake of Sarda ewes. Ital. J. Anim. Sci. 6(Suppl. 1):577-579.

Pulina, G., A. Nudda, G. Battacone, and A. Cannas. 2006. Effects of nutrition on the contents of fat, protein, somatic cells, aromatic compounds, and undesirable substances in sheep milk. Anim. Feed Sci. Technol. 131:255-291.

Rotunno, T., A. Sevi, R. Di Caterina, and A. Muscio. 1998. Effects of graded level of dietary rumen-protected fat on milk characteristics of Comisana ewes. Small Rumin. Res. 30:137-145.

SAS Institute. 1999. SAS User's Guide: Statistics. Version 8.1. SAS Institute Inc., Cary, NC.

Sevi, A., G. Annicchiarico, M. Albenzio, L. Taibi, A. Muscio, and S. Dell'Aquila. 2001. Effects of solar radiation and feeding time on behavior, immune response and production of lactating ewes under high ambient temperature. J. Dairy Sci. 84:629-640. 
Sevi, A., T. Rotunno, R. Di Caterina, and A. Muscio. 2002. Fatty acid composition of ewe milk as affected by solar radiation and high ambient temperature. J. Dairy Res. 69:181-194.

Shapiro, S. S., and M. B. Wilk. 1965. An analysis of variance test for normality. Biometrika 52:591-601.

Silanikove, N. 1992. Effects of water scarcity and hot environment on appetite and digestion in ruminants: A review. Livest. Prod. Sci. 30:175-194.

Toral, P. G., P. Frutos, G. Hervás, P. Gómez-Cortés, M. Juárez, and M. A. de la Fuente. 2010b. Changes in milk fatty acid profile and animal performance in response to fish oil supplementation, alone or in combination with sunflower oil, in dairy ewes. J. Dairy Sci. 93:1604-1615.

Toral, P. G., G. Hervás, P. Gómez-Cortés, P. Frutos, M. Juárez, and M. A. de la Fuente. 2010a. Milk fatty acid profile and dairy sheep performance in response to diet supplementation with sunflower oil plus incremental levels of marine algae. J. Dairy Sci. 93:16551667.

Ulbricht, T. L. V., and D. A. T. Southgate. 1991. Coronary heart disease: Seven dietary factors. Lancet 338:985-992.

Williams, C. M. 2000. Dietary fatty acids and human health. Ann. Zootech. 49:165-180.

Zhang, R. H., A. F. Mustafa, and X. Zhao. 2006a. Effects of flaxseed supplementation to lactating ewes on milk composition, cheese yield, and fatty acid composition of milk and cheese. Small Rumin. Res. 63:233-241.

Zhang, R. H., A. F. Mustafa, and X. Zhao. 2006b. Effects of feeding oilseeds rich in linoleic and linolenic fatty acids to lactating ewes on cheese yield and on fatty acid composition of milk and cheese. Anim. Feed Sci. Technol. 127:220-233. 